\title{
Quality characteristics and antioxidant activity of yogurt dressing containing black currant extract
}

\author{
Kwon Yong Woo, Park Geum Soon* \\ Faculty of Food Service and Technology, Daegu Catholic University, Gyeongsan 38430, Korea \\ 블랙커런트 요구르트 첨가 드레싱의 품질특성 및 항산화성 \\ 권용우 · 박금순* \\ 대구가톨릭대학교 외식산업학 전공
}

\begin{abstract}
This study was carried out to investigate the quality characteristics and antioxidant activity of yogurt dressing prepared with different amounts $(0,5,10,15$, and $20 \%)$ of black currant (Ribes nigrum $L$ ) extract. All samples were evaluated for chemical composition, $\mathrm{pH}$, viscosity, sugar content, color, organic acid content and antioxidant activity. Our findings revealed that with increasing amounts of black currant extract in yogurt dressing, the moisture, crude protein and crude lipid contents decreased. The $\mathrm{pH}$ and viscosity gradually decreased, whereas the sugar increased with increase in black currant extract. Further, the lightness $(L)$ value decreased, while the redness (a) and yellowness (b) values increased with increase in added black currant extract. Among the organic acids, the contents of citric acid, malic acid, succinic acid and acetic acid increased, while that of tartaric acid and lactic acid decreased with increasing levels of added black currant extract. The total polyphenol and total anthocyanin contents were $5.90-245.97 \mathrm{mg} / 100 \mathrm{~g}$ and $0.62-190.09 \mathrm{mg} / 100 \mathrm{~g}$, respectively. In addition, the 1,1-diphenyl2-picrylhydrazyl (DPPH) and 2,2'-azino-bis(3-thylbenzothiazoline-6-sulfonic acid) (ABTS) radical scavenging activities significantly increased with increase in added black currant extract.
\end{abstract}

Key words : yogurt dressing, black currant, quality characteristics.

\section{서 론}

최근 건강에 대한 소비자들의 관심이 증대됨에 따라 영 양분 섭취와 질병 예방 차원에서 각종 과실과 이를 활용한 여러 가공품에 대한 소비 및 제품 개발에 관한 연구가 활발 히 진행되고 있다(1-2). 소과류(small fruits)는 낙엽과수 중 액과(berry)를 착생하는 과수로 정식 1-2년째에 열매를 맺 고 나무높이가 1-2 m로 낮아 과실 수확이 비교적 용이하다. 소과류에는 페놀화합물인 플라보노이드, 안토시아닌 등 천 연생리활성 물질이 다량 함유하고 있다. 그 중 베리(berry)

*Corresponding author. E-mail : gspark@cu.ac.kr Phone : 82-53-850-3512, Fax: 82-53-359-6853

Received 16 January 2018; Revised 19 February 2018; Accepted 22 February 2018.

Copyright (c) The Korean Society of Food Preservation. All rights reserved.
류는 국내 시장에서 오랫동안 딸기가 주종을 이루었으나 최근 베리류의 인기가 급상승하면서 해외로부터 다양한 종류가 지속해서 수입되고 있다(3). 특히 베리에는 polyphenols, phenolic acids, flavonoids 및 carotenoide 화합물의 함량이 높을 뿐 아니라 비타민 $\mathrm{C}$, 안토시아닌 등의 여러 생리활성 물질을 함유하고 있다(4).

건강에 대한 소비자의 관심이 높아지면서 샐러드류를 주요 재료로 많이 이용되어 전통채소나 서양의 특수 채소의 소비가 증가하고 있는 추세이다(5). 샐러드는 식사 전 식욕 을 돋우어 주고 채소의 아삭한 질감과 맛, 향을 증진시켜 주며, 건강 유지에 필요한 비타민과 무기질을 섭취하는데 용이한 음식이다(6). 그와 곁들여지는 드레싱은 대개 차가 운 종류의 소스를 말하며, 남유럽은 식초(vinaigrette)가 주 재료로 사용되고 동유럽에서는 마요네즈를 기반으로 한 것을 말한다(7). 드레싱은 음식의 색상과 풍미를 부여하여 샐러드의 맛을 더해 주지만(8) 우리나라 사람들이 많이 사 
용하는 드레싱인 마요네즈는 조지방 $70-80 \%$, 수분 $12-16 \%$, 조단백질 2-3\%, 회분 1-2\% 등으로 조지방 함량이 많아 성인 병 유발에 대한 우려가 있다(9).

따라서 현대인의 드레싱 선호형태는 칼로리가 낮은 건강 기능성 드레싱을 더 선호하는 추세이며, 최근 드레싱 관련 연구에서 오디즙(9), 매실(10), 유자즙(11), 복분자즙(12), 아로니아즙(13) 등을 첨가하여 지방함량과 칼로리를 줄이 는 건강기능성 드레싱에 대한 연구들이 보고되고 있다.

요구르트는 우유의 영양과 소화율이 향상된 유제품으로 혈중 콜레스테롤을 감소시키고, 비타민과 무기질 흡수촉진 및 대장암 발생률의 저하 등(14)의 다양한 생리기능으로 인하여 세계적으로 가장 큰 기호식품 중 하나이자 건강음료 로 알려져 있으나(15) 기능성 재료를 첨가한 요구르트 드레 싱에 대한 연구는 미흡한 실정이다 $(14,16)$.

따라서 본 연구에서는 안토시아닌과 폴리페놀 등의 항산 화제 물질과 생리활성 성분을 다량 함유하고 있는 블랙커런 트를 첨가한 요구르트 드레싱을 제조한 후 품질 특성과 항산화성을 비교하여 현대인의 건강에 기여할 수 있는 기능 성 높인 식품을 개발하고자 하였다. 이에 블랙커런트 첨가 량을 달리하여 요구르트 드레싱을 제조하고 최적 첨가량을 선정하여 새로운 건강 기능성 요구르트 드레싱 개발 가능성 을 위한 기초자료로 제공하고자 하였다.

\section{재료 및 방법}

\section{실험 재료}

본 실험에서 사용한 요구르트 드레싱 제조에 사용된 플 레인 요구르트(동원 데어리푸드, (주동원 $\mathrm{F} \& \mathrm{~B}$, 경기도, 한 국), 레몬주스(lazy lemon, Polenghi LAS s.r.l., Milano, Italy), 꿀(아카시아 벌꿀, 동서식품, 충북, 한국), 소금(오천년의 신비 꽃소금, 백설, 전남, 한국), 백후추(미담채 백후추, (주푸 드 코리아, 경기도, 한국)는 대형마트에서 구입하여 사용하 였다. 블랙커런트는 농축액 $100 \%$ (뉴질랜드산)를 경기 화성 베이스이즈 제조사에서 구입하여 시료로 사용하였다.

\section{블랙커런트 첨가 요구르트 드레싱 제조}

요구르트 드레싱의 재료 배합비는 Table 1과 같으며 Park 등(13)과 Lee와 Lee(14)의 방법을 참고하여 예비실험을 거 친 후 제조하였다. 제조 방법은 mixing bowl에 요구르트, 레몬즙, 꿀, 소금, 백후추를 첨가하여 2 분간 blender로 교반 하고 각 시료마다 블랙커런트 0-20\%를 첨가하여 2분간 교 반하여 분석시료로 사용하였다.

\section{일반성분 분석}

일반성분 분석은 $\mathrm{AOAC}$ 법(17)에 따라 실시하였다. 수분 함량은 $105^{\circ} \mathrm{C}$ 상압가열건조법, 조단백질은 Kjeldahl 질소정 량법, 조지방은 Soxhelt법, 회분은 $550^{\circ} \mathrm{C}$ 직접회화법을 사용
하였고 탄수화물은 100 에서 수분, 조단백, 조지방 및 회분 을 뺀 값으로 사용하였다.

Table 1. Mixing ratio of the ingredients used in making yogurt dressing

\begin{tabular}{cccccc}
\hline \multirow{2}{*}{ Ingredient (g) } & \multicolumn{5}{c}{ Samples $^{10}$} \\
\cline { 2 - 6 } & Control & BY5 & BY10 & BY15 & BY20 \\
\hline Yogurt & 300 & 285 & 270 & 255 & 240 \\
Black currant & 0 & 15 & 30 & 45 & 60 \\
Lemon juice & 20 & 20 & 20 & 20 & 20 \\
Honey & 25 & 25 & 25 & 25 & 25 \\
Salt & 1 & 1 & 1 & 1 & 1 \\
White pepper & 0.5 & 0.5 & 0.5 & 0.5 & 0.5 \\
\hline
\end{tabular}

${ }^{1)}$ Control, yogurt dressing added with black currant; BY5, yogurt dressing added with $50 \%$ black currant; BY10, yogurt dressing added with $10 \%$ black currant; BY15, yogurt dressing added with $15 \%$ black currant; BY20, yogurt dressing added with $20 \%$ black currant.

\section{$\mathrm{pH}$, 당도와 점도}

$\mathrm{pH}$ 는 $\mathrm{pH}$ meter(Metrohn AG CH-91, Hanna, Mauritius, USA)를 사용하여 측정하였고 시료의 당도는 Master Refractometer(ATAGO, N-1E, ${ }^{\circ}$ Brix 0-33\%, Kyoto, Japan)를 이용하여 측정하였으며 점도는 viscometer(DVE Viscometer, Coretech, Brookfield, IL, USA)를 이용하여 $12 \mathrm{rpm}$ 으로 spindle No.18을 사용하여 상온에서 측정하였으며 spindle 이 돌기 시작한 후 1 분 정도 되는 순간의 점도는 $\mathrm{cP}($ centipoise)단위로 읽었다.

색 도

각 시료를 색차계(CR-400, Minolta Co., Ltd., Osaka, $\mathrm{Japan}$ )를 사용하여 L 값(명도), a 값(적색도), $\mathrm{b}$ 값(황색도)을 3회 반복 측정하여 평균값으로 나타내었다. 이 때 사용된 표준백반은 $\mathrm{L}$ 값 $94.60, \mathrm{a}$ 값 $0.00, \mathrm{~b}$ 값 2.75 로 보정하였다.

\section{유기산 분석}

유기산 분석은 Sung과 Choi(15)의 방법을 참고하여 시료 액 $2 \mathrm{~mL}$ 에 증류수 $20 \mathrm{~mL}$ 를 넣고 혼합한 후 원심분리기 $3,000 \mathrm{rpm}$ 에서 30 분간 원심분리하여 얻은 상등액을 0.45 $\mu \mathrm{m}$ filter로 여과 후 희석하여 HPLC sample로 사용하였다. 이때 표준물질은 citric acid, malic acid, tartaric acid, succinic acid, lactic acid 및 acetic acid를 사용하였다. 유기산은 표준 유기산의 각 retention time을 확인하고 그 때의 표준 유기산 면적과 시료의 면적으로부터 함량을 계산하였다. 모든 시 료는 3회 반복 측정하여 그 평균값으로 나타내었으며 분석 조건은 Column(Aminex RHPX-87H, $7.5 \times 300 \mathrm{~mm}, 9 \mu \mathrm{m}$, BIO-RAD Laboratories, Berkeley, CA, USA), Flow rate 0.6 $\mathrm{mL} / \mathrm{min}$, Injection volume $20 \mu \mathrm{L}$, Detector PDA $214 \mathrm{~nm}$ 로 분석하였다. 


\section{항산화능}

Polyphenol 함량은 Folin-Denis(18)의 방법을 참고하여 시료 $1 \mathrm{~g}$ 에 에탄올 $20 \mathrm{~mL}$ 를 가하여 $40^{\circ} \mathrm{C}$ 에서 16 시간 교반시 킨 후 상등액을 $0.2 \mu \mathrm{m}$ membrane filter로 여과시켰다. 여액 $0.1 \mathrm{~mL}$ 에 $2 \%$ sodium carbonate $3 \mathrm{~mL}$ 를 가한 후 3 분간 방치 시킨 후 Folin-Ciocalteu's reagent $0.2 \mathrm{~mL}$ 를 첨가하여 상온에 서 30분간 반응시킨 후 분광광도계(Optizen POP, Mecasys Co., Daegeon, Korea)를 이용하여 $750 \mathrm{~nm}$ 에서 측정하였고, 표준곡선은 gallic acid를 이용하여 검량선에 의하여 함량을 산출하였다.

총 안토시아닌 함량은 $\mathrm{pH}$ differential method(19)에 따라 측정하였다. $1 \mathrm{mg} / \mathrm{mL}$ 시료 $0.5 \mathrm{~mL}$ 에 $0.025 \mathrm{M}$ potassium chloride buffer( $\mathrm{pH}$ 1.0)와 $0.4 \mathrm{M}$ sodium acetate buffer( $\mathrm{pH}$ 4.5)를 가하여 최종 부피를 $5 \mathrm{~mL}$ 로 한 다음 510 및 700 $\mathrm{nm}$ 에서 반응 액의 흡광도를 각각 측정하여 아래의 식으로 결과를 얻었다.

Anthocyanin pigment(cyaniding-3-glucoside equivalents, $\mathrm{mg} / \mathrm{L}$ ) $=\mathrm{A} \times \mathrm{MW} \times \mathrm{DF} \times 10^{3} / \varepsilon \times 1$

$\mathrm{A}($ absorbance value $)=\left(\mathrm{A}_{510} \mathrm{~mm}-\mathrm{A}_{700} \mathrm{~m}\right) \mathrm{pH}$ 1.0-( $\left.\mathrm{A}_{510 \mathrm{~mm}} \mathrm{~A}_{700 \mathrm{~mm}}\right) \mathrm{pH} 4.5$ $\mathrm{MW}$ (molecular weight of cyanidin-3-glucoside) $=449.2 \mathrm{~g} / \mathrm{mol}$ $\mathrm{DF}$ (dilution factor)=dilution ratio of sample

$\varepsilon$ (cyanidin-3-glucoside molar absorbance $)=26,900$ molar extinction coefficient, in $\mathrm{L} \times \mathrm{mol}^{-1} \times \mathrm{cm}^{-1}$

$1=$ pathlength in $\mathrm{cm}$

$\mathrm{DPPH}$ 라디칼 소거법은 Blois(20)의 방법을 참고하여 측 정하였다. 즉 시료 $5 \mathrm{~g}$ 에 에틸알코올 $50 \mathrm{~mL}$ 를 가하여 stirrer 로 균질화 한 후 $3,600 \mathrm{rpm}$ 에 20 분간 원심분리하여 상등액 $3 \mathrm{~mL}$ 와 $\mathrm{DPPH}$ 용액 $6 \mathrm{~mL}$ 를 가하여 혼합한 뒤 30 분간 정치 한 후 spectrophotometer(Optizen 3220UV, Mecasys Co., Ltd., Daejeon, Korea)를 이용하여 $517 \mathrm{~nm}$ 에서 흡광도를 측정하였으며 아래의 식에 의해 전자공여능을 산출하였다.

DPPH radical scavenging activity $(\%)=$

$$
\left(1-\frac{\text { absorbance of sample }}{\text { absorbance value of control }}\right) \times 100
$$

$\mathrm{ABTS}$ 라디칼 소거능 측정법은 Roberta 등(21)의 방법을 참고하여 $\mathrm{ABTS}$ 라디칼 소거능을 측정하였다. 시료 $10 \mathrm{~g}$ 에 $80 \%$ ethanol $100 \mathrm{~mL}$ 를 가하여 stirrer로 24시간 실온에서 추출한 후 $3,600 \mathrm{rpm}$ 에 20 분간 원심분리하여 상등액을 취하 여 시료로 사용하였다. 실온에서 24시간 추출 후 원심 7.4 $\mathrm{mM}$ ABTS와 $2.6 \mathrm{mM}$ potassium persulfate를 암소에 24시간 방치하여 양이온(ABTS+)을 형성시킨 후, $750 \mathrm{~nm}$ 에서 흡광
도의 값이 1.7 이하가 되도록 에탄올을 이용하여 희석하였 다. 희석된 용액 $1 \mathrm{~mL}$ 과 시료 $20 \mu \mathrm{L}$ 를 30 분 동안 반응시킨 다음 microplate reader를 이용하여 $750 \mathrm{~nm}$ 에서 흡광도를 측정하였다. ABTS 라디칼 소거능은 다음 식에 의하여 백분 율로 나타내었다.

ABTS radical scavenging activity $(\%)=$

$$
\text { (1- } \left.\frac{\text { A experiment }}{\text { A control }}\right) \times 100
$$

아질산염 소거능 측정

$\mathrm{Kim}$ 등(22)의 방법을 변형하여 아질산염 소거능을 측정 하였으며 시료는 시료 $10 \mathrm{~g}$ 에 $80 \%$ ethanol $100 \mathrm{~mL}$ 를 가하여 stirrer로 24 시간 실온에서 추출 한 후 $3,600 \mathrm{rpm}$ 에 20 분간 원심분리하여 상등액을 취하였다. 각 시료 $1 \mathrm{~mL}$ 및 $1 \mathrm{mM}$ $\mathrm{NaNO}_{2}$ 용액 $1 \mathrm{~mL}$ 을 혼합한 뒤 $0.1 \mathrm{M} \mathrm{HCl}$ 을 이용하여 $\mathrm{pH} 1.2$ 로 보정하였다. 다음 $37^{\circ} \mathrm{C}$ 에서 1 시간 반응시킨 후 반응액 $1 \mathrm{~mL}$ 에 $2 \%$ acetic acid $5 \mathrm{~mL}$ 과 griess reagent 0.4 $\mathrm{mL}$ 를 첨가하여 혼합한 뒤 상온에서 15 분간 방치하였다. 다음 microplate reader를 이용하여 $520 \mathrm{~nm}$ 에서 흡광도를 측정하였다. 아질산염 소거능은 다음 식에 대입하여 값을 백분율로 나타내었다.

Nitrite scavenging ability $(\%)=\left(1-\frac{\text { A experiment }}{\text { A control }}\right) \times 100$

\section{통계처리}

모든 실험은 3회 반복 실험하였으며, 분산분석(ANOVA) 및 다중범위 검정(Duncan's multiple range test)에 의해 유의 성 검정을 하였다. 모든 통계자료는 computer program package인 SAS 9.1(SAS Institute, Cary, NC, USA)을 사용하 였다.

\section{결과 및 고찰}

블랙커런트 요구르트 드레싱의 일반성분

블랙커런트를 첨가한 요구르트 드레싱의 일반성분 분석 결과는 Table 2 와 같다. 블랙커런트를 첨가한 요구르트 드 레싱의 수분함량은 대조군이 $76.13 \%$ 로 가장 높게 나타났으 며, 블랙커런트 첨가 요구르트군은 68.85-74.50\%로 블랙커 런트를 첨가량이 많아질수록 유의적으로 감소하는 결과를 나타내었다 $(\mathrm{p}<0.001)$.

조단백질은 대조군이 $3.88 \%$ 로 가장 높게 나타났으며 블 랙커런트 첨가량이 증가할수록 감소하였다. 조지방은 블랙 커런트 $20 \%$ 첨가 요구르트 드레싱이 $3.37 \%$ 로 유의적으로 
Table 2. Chemical composition of yogurt dressing with black currant

\begin{tabular}{|c|c|c|c|c|c|c|}
\hline \multirow{2}{*}{$\begin{array}{c}\text { Composition } \\
(\%)\end{array}$} & \multicolumn{5}{|c|}{ Sample $^{1)}$} & \multirow{2}{*}{ F-value } \\
\hline & Control & BY5 & BY10 & BY15 & BY20 & \\
\hline Moisture & $76.13 \pm 0.81^{2 / 23)}$ & $74.50 \pm 0.6^{b}$ & $73.39 \pm 0.54^{c}$ & $71.27 \pm 0.25^{\mathrm{d}}$ & $68.85 \pm 0.51^{\mathrm{e}}$ & $73.31^{* * * 4)}$ \\
\hline Crude protein & $3.88 \pm 0.03^{\mathrm{a}}$ & $3.76 \pm 0.01^{\mathrm{b}}$ & $3.65 \pm 0.04^{\mathfrak{c}}$ & $3.41 \pm 0.01^{\mathrm{d}}$ & $3.44 \pm 0.02^{\mathrm{e}}$ & $198.69^{* * *}$ \\
\hline Crude lipid & $3.56 \pm 0.04^{\mathrm{a}}$ & $3.45 \pm 0.05^{b}$ & $3.42 \pm 0.01^{b c}$ & $3.39 \pm 0.01^{c}$ & $3.37 \pm 0.01^{\mathrm{c}}$ & $20.40^{* * *}$ \\
\hline Crude ash & $1.43 \pm 0.01^{\mathrm{e}}$ & $1.46 \pm 0.01^{\mathrm{d}}$ & $1.51 \pm 0.01^{\mathrm{c}}$ & $1.53 \pm 0.01^{b}$ & $1.58 \pm 0.00^{\mathrm{a}}$ & $120.95^{* * *}$ \\
\hline Carbohydrate & $14.99 \pm 0.78^{e}$ & $16.83 \pm 0.66^{d}$ & $18.03 \pm 0.53^{\mathrm{c}}$ & $20.30 \pm 0.24^{b}$ & $22.75 \pm 0.52^{\mathrm{a}}$ & $82.75^{* * *}$ \\
\hline
\end{tabular}

${ }^{1)}$ Control, yogurt dressing added with black currant; BY5, yogurt dressing added with 50\% black currant; BY10, yogurt dressing added with 10\% black currant; BY15, yogurt dressing added with $15 \%$ black currant; BY20, yogurt dressing added with $20 \%$ black currant.

${ }^{2)}$ Mean \pm SD triplicate determinations.

${ }^{3) a-e} \mathrm{e}$ Means with different superscripts within a row indicate significant differences $(\mathrm{p}<0.05)$.

$4^{4 * k+} \mathrm{p}<001$.

가장 낮게 나타났으며 블랙커런트 첨가량이 증가할수록 감소하는 결과를 보였다( $\mathrm{p}<0.001)$. 조회분은 $1.43-1.58 \%$ 범 위로 나타났으며 블랙커런트 첨가량이 증가할수록 요구르 트 드레싱의 회분함량이 유의적으로 증가하였다 $(\mathrm{p}<0.001)$. 탄수화물은 대조군이 $14.99 \%$ 로 가장 낮게 나타났으며, 블 랙커런트 첨가량이 증가할수록 $16.83-22.75 \%$ 로 증가하여 전반적으로 블랙커런트 첨가량이 증가할수록 조회분과 탄 수화물은 증가하고 수분함량, 조단백, 조지방은 감소하는 결과를 나타내었다. Jeong 등(2012)의 블랙커런트에 대한 일반성분에서 수분 $77.64 \%$, 조단백 $1.28 \%$, 회분 $0.31 \%$, 조 지방 $0.28 \%$ 로 일반 과실과 수분과 조지방 함량은 비슷하며 조단백질은 높다고 보고한 바 있다. 본 연구에서는 블랙커 런트를 요구르트에 첨가시 주재료의 영향을 받아 수분함량 과 조단백, 조지방이 블랙커런트 첨가량에 따라 감소되었 으리라 사료된다.

\section{$\mathrm{pH}$, 점도와 당도}

블랙커런트를 첨가한 요구르트 드레싱의 $\mathrm{pH}$, 점도와 당 도 측정 결과는 Table 3 과 같다. $\mathrm{pH}$ 는 블랙커런트 $20 \%$ 첨가 요구르트 드레싱이 2.87로 가장 낮게 나타났으며, 대조군이 3.50 으로 가장 높게 나타났다. 이는 블랙커런트에 함유되어 있는 다양한 유기산(citric acid, tartaric acid, malic acid, acetic acid 등)에 기인된 것으로 사료된다. Park 등(13)의 아로니아즙 첨가 요구르트 드레싱의 품질특성 연구에서도 아로니아즙 첨가량이 증가할수록 $\mathrm{pH}$ 가 감소한다는 연구결 과와 유사한 경향을 보였다.

점도는 유동식품의 흐름에 대한 저항성을 나타내는 것으 로 점도가 높을수록 흐름성이 적고 점도가 낮을수록 흐름성 이 높다(14). 대조군의 점도는 $4,333.33 \mathrm{cP}$ 이었으며 블랙커 런트 첨가량이 증가할수록 감소하였으며 블랙커런트 $20 \%$ 첨가 요구르트 드레싱은 $2,746.67 \mathrm{cP}$ 로 유의적으로 감소하 였다(p<0.001). 이는 오디즙을 첨가한 요구르트 드레싱의 점도 결과(24)와 복분자 첨가 요구르트 드레싱의 점도 결과 (12)에서도 오디즙과 복분자 첨가량이 증가할수록 낮아졌 다는 연구결과와 일치하였다. 반면 Lee와 Lee(14)의 블루베 리 첨가 요구르트 드레싱에서는 블루베리 첨가량이 증가할 수록 점도가 높아져 본 연구와 차이를 보였다. 이는 주재료 인 요거트와 첨가재료의 점성, 비중, 고형분 등이 다르기 때문으로 사료된다.

당도는 대조군이 $16.10{ }^{\circ} \mathrm{Brix}(\%)$ 으로 가장 낮게 나타났으 며 블랙커런트 첨가 요구르트 드레싱군은 18.03-25.20 ${ }^{\circ} \mathrm{Brix}(\%)$ 으로 블랙커런트 첨가량이 증가할수록 높아지는 결과를 보였다. 이는 Park 등(13) 아로니아즙 첨가 요구르트 드레싱과 Lee와 Lee(14)의 블루베리 첨가 요구르트 드레싱

Table 3. $\mathrm{pH}$, viscosity and sugar content of yogurt dressing with black currant

\begin{tabular}{ccccccc}
\hline \multirow{2}{*}{ characteristics } & \multicolumn{5}{c}{ Sample } & F \\
\cline { 2 - 5 } & Control & BY5 & BY10 & BY15 & BY20 & \\
\hline pH & $3.50 \pm 0.02^{2 / 233)}$ & $3.15 \pm 0.01^{\mathrm{b}}$ & $2.93 \pm 0.02^{\mathrm{c}}$ & $2.88 \pm 0.12^{\mathrm{d}}$ & $2.87 \pm 0.01^{\mathrm{d}}$ & $1442.42^{* * * 4)}$ \\
Viscosity (cP) & $4333.33 \pm 75.72^{\mathrm{a}}$ & $3704.00 \pm 86.53^{\mathrm{b}}$ & $3063.33 \pm 85.04^{\mathrm{c}}$ & $2826.67 \pm 28.87^{\mathrm{d}}$ & $2746.67 \pm 57.74^{\mathrm{d}}$ & $275.85^{* * *}$ \\
Sugar content ( ${ }^{\circ}$ Brix) & $16.10 \pm 0.10^{\mathrm{e}}$ & $18.03 \pm 0.21^{\mathrm{d}}$ & $21.07 \pm 0.06^{\mathrm{c}}$ & $24.00 \pm 0.00^{\mathrm{b}}$ & $25.20 \pm 0.10^{\mathrm{a}}$ & $3340.33^{* * *}$ \\
\hline
\end{tabular}

${ }^{17}$ Control, yogurt dressing added with black currant; BY5, yogurt dressing added with 50\% black currant; BY10, yogurt dressing added with 10\% black currant; BY15, yogurt dressing added with $15 \%$ black currant; BY20, yogurt dressing added with $20 \%$ black currant.

${ }^{2)}$ Mean \pm SD triplicate determinations.

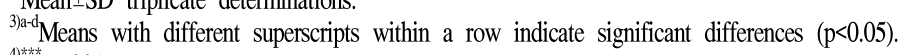

4) ${ }^{\star \star *}<.001$. 
에서는 아로니아즙과 블루베리 첨가량이 증가할수록 당도 가 유의적으로 감소하는 연구결과와 상반된 결과를 보였으 나 $\operatorname{Park}(9)$ 의 오디즙 첨가 요구르트 드레싱에서는 오디즙 첨가량이 증가할수록 당도가 증가하여 본 연구와 일치하는 경향을 보였다. 이는 부재료 당도의 차이로 기인하며 블랙 커런트 당도가 $60{ }^{\circ} \mathrm{Brix}$ 로 대조군의 당도에 비해 높은 수치 를 보여 블랙커런트 첨가 요구르트 드레싱에 영향을 미친 것으로 사료된다.

색 도

블랙커런트 첨가 요구르트 드레싱의 색도 결과는 Table 4 와 같다. 블랙커런트를 첨가한 요구르트 드레싱의 $\mathrm{L}$ 값은 대조군이 74.65로 가장 높게 나타났으며 블랙커런트 첨가 량이 증가할수록 감소하여 블랙커런트 $20 \%$ 첨가 요구르트 드레싱이 24.46으로 유의적으로 가장 낮게 나타났다 (p<0.001). a 값은 대조군이 -1.85로 녹색 (-a값은 녹색)으로 나타났으나 블랙커런트의 첨가량이 많아질수록 23.9025.23 의 범위로 유의적으로 증가하여 블랙커런트 $20 \%$ 첨 가가 가장 높은 a 값은 보였다 $(\mathrm{p}<0.001) . \mathrm{b}$ 값은 대조군이 -0.67 이고 블랙커런트 첨가량이 많아질수록 유의적으로 증 가하는 경향을 보였다 $(\mathrm{p}<0.001)$. 이는 블랙커런트의 빛깔이 검은색에 가까운 짙은 보랏빛을 보이는데 안토시아닌이
풍부하게 들어있기 때문이라고 사료되며 이것은 블랙커런 트 첨가량이 증가할수록 요구르트 드레싱의 명도 $\mathrm{L}$ 값은 감소하고, $\mathrm{a}$ 값과 $\mathrm{b}$ 값은 증가에 영향을 미치는 것으로 보인 다. Park과 Chung(25)의 블랙커런트 분말을 첨가한 양갱의 품질특성에서 블랙커런트 첨가량이 증가할수록 양갱의 $\mathrm{L}$ 값은 감소하고 a 값은 증가하였다고 보고하여 본 실험의 결과와 유사한 경향을 보였다. 또한 복분자즙 첨가 요구르 트 드레싱(13)와 오디즙을 첨가한 요구르트 드레싱(9)의 색도에서 $\mathrm{L}$ 값은 감소하고, $\mathrm{a}$ 값과 $\mathrm{b}$ 값은 증가한다는 연구결과와 일치하였다.

\section{유기산 함량}

블랙커런트 첨가 요구르트 드레싱의 유기산 분석 결과는 Table 5와 같다. 유기산 종류로는 citric acid, tartaric acid, malic acid, succinic acid, lactic acid, acetic acid로 총 6종이 검출되었다. 신맛뿐만 아니라 기능성을 나타내는 중요한 유기산인 citric acid는 대조군이 $121.41 \mathrm{ppm}$ 으로 블랙커런 트를 첨가할수록 479.72-1,498.65 ppm으로 유의적으로 증 가하는 결과를 나타냈다( $<<0.001)$. Tartaric acid는 대조군이 $190.32 \mathrm{ppm}$ 으로 블랙커런트를 첨가할수록 감소하였으며, malic acid는 블랙커런트 첨가량이 증가할수록 높았으며

Table 4. Hunter's color value of yogurt dressing with black currant

\begin{tabular}{ccccccc}
\hline \multirow{2}{*}{ Color } & \multicolumn{5}{c}{ Sample $^{1)}$} & F-value \\
\cline { 2 - 5 } & Control & BY5 & BY10 & BY15 & BY20 & $4,650.92^{* * * 4)}$ \\
\hline L & $74.65 \pm 0.02^{2 / \mathrm{a} 3)}$ & $39.03 \pm 0.42^{\mathrm{b}}$ & $28.49 \pm 0.77^{\mathrm{c}}$ & $26.00 \pm 0.80^{\mathrm{d}}$ & $24.46 \pm 0.09^{\mathrm{e}}$ & $16,383.5^{* * *}$ \\
a & $-1.85 \pm 0.01^{\mathrm{e}}$ & $23.90 \pm 0.21^{\mathrm{d}}$ & $24.44 \pm 0.27^{\mathrm{c}}$ & $24.77 \pm 0.11^{\mathrm{b}}$ & $25.23 \pm 0.07^{\mathrm{a}}$ & \\
b & $-0.67 \pm 0.23^{\mathrm{e}}$ & $0.52 \pm 0.06^{\mathrm{d}}$ & $3.85 \pm 0.16^{\mathrm{c}}$ & $5.70 \pm 0.23^{\mathrm{b}}$ & $6.14 \pm 0.03^{\mathrm{a}}$ & $1,050.65^{* * *}$ \\
\hline
\end{tabular}

${ }^{1)}$ Control, yogurt dressing added with black currant; BY5, yogurt dressing added with 50\% black currant; BY10, yogurt dressing added with 10\% black currant; BY15, yogurt dressing added with $15 \%$ black currant; BY20, yogurt dressing added with $20 \%$ black currant.

${ }^{2}$ Mean \pm SD triplicate determinations.

${ }^{3) a-e}$ Means with different superscripts within a row indicate significant differences $(\mathrm{p}<0.05)$.

${ }^{4)^{* * *}} \mathrm{p}<.01$.

Table 5. Organic acid of yogurt dressing with black currant

\begin{tabular}{ccccccc}
\hline \multirow{2}{*}{$\begin{array}{c}\text { Organic acid } \\
(\mathrm{ppm})\end{array}$} & Control & BY5 & Sample & \multicolumn{2}{c}{ F-value } \\
\cline { 2 - 6 } & $\left.121.41 \pm 0.17^{2) 3}\right)$ & $479.72 \pm 3.97^{\mathrm{d}}$ & $909.80 \pm 4.21^{\mathrm{c}}$ & $980.61 \pm 6.51^{\mathrm{b}}$ & $1,498.65 \pm 0.64^{\mathrm{a}}$ & $\left.53,855.9^{* * * 4}\right)$ \\
Citric acid & $190.32 \pm 0.12^{\mathrm{a}}$ & $94.31 \pm 0.15^{\mathrm{b}}$ & $90.57 \pm 0.38^{\mathrm{c}}$ & $82.15 \pm 2.53^{\mathrm{d}}$ & $79.04 \pm 0.07^{\mathrm{e}}$ & $4,974.20^{* * *}$ \\
Tartaric acid & $37.68 \pm 0.75^{\mathrm{e}}$ & $86.39 \pm 1.07^{\mathrm{d}}$ & $130.74 \pm 8.53^{\mathrm{c}}$ & $143.62 \pm 3.48^{\mathrm{b}}$ & $161.17 \pm 1.17^{\mathrm{a}}$ & $413.24^{* * *}$ \\
Malic acid & $0.00 \pm 0.00^{\mathrm{e}}$ & $25.16 \pm 1.06^{\mathrm{d}}$ & $119.41 \pm 6.60^{\mathrm{c}}$ & $135.52 \pm 1.85^{\mathrm{b}}$ & $201.05 \pm 0.29^{\mathrm{a}}$ & $2,132.81^{* * *}$ \\
Succinic acid & $644.23 \pm 20.70^{\mathrm{a}}$ & $603.45 \pm 8.02^{\mathrm{b}}$ & $599.17 \pm 11.60^{\mathrm{b}}$ & $546.89 \pm 0.23^{\mathrm{c}}$ & $433.28 \pm 6.42^{\mathrm{d}}$ & $149.19^{* * *}$ \\
Lactic acid & $1,057.05 \pm 21.38^{\mathrm{e}}$ & $1,251.81 \pm 11.41^{\mathrm{d}}$ & $2,175.94 \pm 35.07^{\mathrm{c}}$ & $2,379.71 \pm 9.24^{\mathrm{b}}$ & $2,726.02 \pm 6.90^{\mathrm{a}}$ & $418.76^{* * *}$ \\
Acetic acid & &
\end{tabular}

${ }^{1)}$ Control, yogurt dressing added with black currant; BY5, yogurt dressing added with $50 \%$ black currant; BY10, yogurt dressing added with $10 \%$ black currant; BY15, yogurt dressing added with $15 \%$ black currant; BY20, yogurt dressing added with $20 \%$ black currant.

${ }^{2)}$ Mean \pm SD triplicate determinations.

${ }^{3) \text { a-e }}$ Means with different superscripts within a row indicate significant differences $(\mathrm{p}<0.05)$

4) $\mathrm{p}<.001$. 
블랙커런트 $20 \%$ 첨가 요구르트 드레싱은 $161.17 \mathrm{ppm}$ 으로 가장 높게 나타났다. Succinic acid는 대조군에서는 검출되 지 않았으나 블랙커런트를 첨가할수록 증가하여 블랙커런 트 첨가 요구르트 드레싱군에서는 25.16-433.28 ppm범위로 나타났다. 블루베리즙을 첨가한 요구르트 드레싱(14)의 유 기산 결과 블루베리즙을 첨가할수록 citric acid, tartaric acid, malic acid, succinic acid는 증가하고 lactic acid는 감소하여 본 연구와 경향이 비슷한 것으로 나타났으나 acetic acid는 높은 함량을 보였다.

\section{폴릭페놀 함량 및 항산화 활성}

블랙커런트를 첨가한 요구르트 드레싱의 총 폴리페놀 함량은 Table 6과 같다. 대조군은 $5.90 \mathrm{mg} / 100 \mathrm{~g}$ 로 가장 낮은 값을 나타냈으며 블랙커런트 첨가 요구르트군은 74.06-245.97 mg/100 g로 블랙커런트 첨가량이 증가할수록 유의적으로 증가하는 결과를 보였다 $(\mathrm{p}<0.001)$. 안토시아닌 함량 또한 대조군은 $0.62 \mathrm{mg} / 100 \mathrm{~g}$ 로 가장 낮은 값을 보였으 나 블랙커런트 $20 \%$ 첨가 요구르트 드레싱은 $190.09 \mathrm{mg} / 100$ $\mathrm{g}$ 로 블랙커런트 첨가량이 증가할수록 유의적으로 높아져 $(\mathrm{p}<0.001)$ 총 폴리페놀 함량과 같은 경향을 보여주었다. Park과 Chung(25)의 블랙커런트를 첨가한 양갱의 품질특성 에서 블랙커런트 분말 첨가가 증가할수록 총 폴리페놀과 총 안토시아닌 함량이 증가한다고 보고하여 블랙커런트 요구르트 첨가군이 대조군보다 항산화 활성도 우수할 것으 로 사료된다. 또한 Jeong 등(26)은 블랙커런트에 존재하는 주된 폴리페놀에는 hydroxybenzoic acid, hydroxycinnamic acid, myricetin, quercetin 및 kaempferol이 있고 안토시아닌 으로는 cyanidin 3-O-rutinoside, delphinidin 3-O-rutinoside, cyanidin 3-O-glucoside 및 delphinidin 3-O-glucoside 등이 있는 것으로 보고되고 있다(27). DPPH radical 소거능은 짙은 자색을 나타내는 DPPH radical이 항산화 물질과 만나 전자나 수소를 제공받으며 탈색되는 원리(28)를 이용하는
방법으로 측정하며 색이 엷어지는 정도가 클수록 항산화 활성이 크다. 블랙커런트를 첨가할수록 요구르트 드레싱의 $\mathrm{DPPH}$ radical 소거능은 대조군이 $3.26 \%$ 로 가장 낮았고 블 랙커런트 첨가 요구르트 드레싱군은 29.76-77.15\%로 블랙 커런트 첨가량이 증가할수록 증가하는 결과를 나타내어 블랙커런트 $20 \%$ 첨가 요구르트 드레싱이 가장 높은 소거능 을 보였다(p<0.001). 이는 오디분말을 첨가한 요구르트(15) 와 머루분말을 첨가한 샐러드 드레싱(7)에서도 오디분말과 머루분말을 첨가함에 있어 생리활성물질인 총 폴리페놀과 안토시아닌을 다량함유한 부재료의 첨가로 인하여 항산화 능이 증가한다고 보고한 연구결과와 일치하였다.

ABTS radical 소거능은 청록색의 ABTS cation radical이 추출물 중의 항산화 물지에 의하여 제거되면 탈색되는 원리 를 이용하여 측정하는 방법이다(29). 블랙커런트 첨가 요구 르트 드레싱의 ABTS radical 소거능 결과는 대조군이 $1.29 \%$, 블랙커런트 첨가 요구르트 드레싱군은 19.80$66.15 \%$ 로 블랙커런트 첨가량 증가에 따라 유의적으로 증가 하였다(p<0.001). 블랙커런트 분말을 첨가한 양갱(25)의 경 우 ABTS radical 소거능은 대조군이 $6.2 \%$, 첨가군이 $38.93-97.81 \%$ 로 높은 소거능을 보여 본 실험과 일치한 결과 를 보였다. 이는 블랙커런트에 함유되어 있는 폴리페놀 및 안토시안닌 함량이 ABTS radical 소거능에 관여한 것으로 판단된다.

아질산염은 식육제품 및 수산물의 가공, 저장과정 중에 독소생성억제, 발색 및 산패 방지를 위하여 첨가되는 것으 로 과다 섭취 시 독성을 나타내어 methemoglobin증과 같은 각종 중독 증상을 유발한다(22). 블랙커런트 첨가 드레싱의 대조군은 $43.27 \%$ 로 가장 낮았으며 블랙커런트 첨가농도에 따라 62.55-89.32로 증가하여 대조군에 비해 아질산염 소거 능이 높게 나타났다. 블랙커런트의 페놀성 물질이 아질산 염 니트로화 반응을 억제하여 블랙커런트를 첨가한 드레싱 을 제조할 경우 항산화 활성 및 생리활성에 긍정적인 영향 을 주리라 사료된다.

Table 6. Total polyphenol content and antioxidant activity of yogurt dressing with black currant

\begin{tabular}{ccccccc}
\hline \multirow{2}{*}{$\begin{array}{c}\text { Antioxidant } \\
\text { activity }\end{array}$} & \multicolumn{5}{c}{ Sample $^{1)}$} & F-value \\
\cline { 2 - 5 } Control $^{1)}$ & BY5 & BY10 & BY15 & BY20 & \\
\hline Total polyphenol (mg/100 g) & $5.90 \pm 0.00^{2) e 3)}$ & $74.06 \pm 0.17^{\mathrm{d}}$ & $132.44 \pm 0.53^{\mathrm{c}}$ & $218.20 \pm 4.55^{\mathrm{b}}$ & $245.97 \pm 1.78^{\mathrm{a}}$ & $\left.6,132.78^{* * * 4}\right)$ \\
Anthocyanin (mg/100 g) & $0.62 \pm 0.28^{\mathrm{e}}$ & $50.93 \pm 0.44^{\mathrm{d}}$ & $105.65 \pm 0.39^{\mathrm{c}}$ & $167.49 \pm 1.42^{\mathrm{b}}$ & $190.09 \pm 1.59^{\mathrm{a}}$ & $18,788.2^{* * *}$ \\
DPPH radical scavenging activity (\%) & $3.26 \pm 0.17^{\mathrm{e}}$ & $29.76 \pm 0.33^{\mathrm{d}}$ & $51.71 \pm 0.27^{\mathrm{c}}$ & $70.24 \pm 0.27^{\mathrm{b}}$ & $77.15 \pm 0.45^{\mathrm{a}}$ & $28,377.5^{* * *}$ \\
ABTS $^{5}(\%)$ & $1.29 \pm 0.21^{\mathrm{e}}$ & $19.80 \pm 0.16^{\mathrm{d}}$ & $38.60 \pm 0.35^{\mathrm{c}}$ & $58.73 \pm 0.98^{\mathrm{b}}$ & $66.15 \pm 0.86^{\mathrm{a}}$ & $5,705.16^{* * *}$ \\
NSA $^{6}(\%)$ & $43.27 \pm 0.99^{\mathrm{e}}$ & $62.55 \pm 0.63^{\mathrm{d}}$ & $79.01 \pm 0.84^{\mathrm{c}}$ & $86.41 \pm 0.48^{\mathrm{b}}$ & $89.32 \pm 0.44^{\mathrm{a}}$ & $2,153.80^{* * *}$ \\
\hline
\end{tabular}

${ }^{1}$ Control, yogurt dressing added with black currant; BY5, yogurt dressing added with 50\% black currant; BY10, yogurt dressing added with 10\% black currant; BY15, yogurt dressing added with $15 \%$ black currant; BY20, yogurt dressing added with $20 \%$ black currant.

${ }^{2)}$ Mean \pm SD triplicate determinations.

${ }^{3) a-e}$ Means with different superscripts within a row indicate significant differences $(\mathrm{p}<0.05)$.

$\left.{ }^{4}\right)^{* * *} \mathrm{p}<.001$.

${ }^{5}$ ABTS, 2,2'-azino-bis(3-ethylbenzothiazoline-6-sulphonic acid).

${ }^{6} \mathrm{NSA}$, nitrite scavenging ability. 


\section{요 약}

본 연구는 건강에 대한 소비자들의 관심이 증대됨에 따 라 영양분 섭취와 질병 예방 차원에서 각종 과실과 이를 활용한 제품 개발의 일환으로 베리류 중 블랙커런트 농축액 을 요구르트 대체 $0,5,10,15$, 및 $20 \%$ 비율로 첨가하여 요구르트 드레싱의 품질특성과 항산화성을 분석하였다. 일 반성분 분석에서 블랙커런트 첨가량이 증가할수록 요구르 트 드레싱의 조회분과 탄수화물은 증가하고 수분함량, 조 단백, 조지방은 감소하는 경향을 나타내었다. $\mathrm{pH}$ 와 점도는 블랙커런트 첨가량이 증가됨에 따라 유의적으로 감소하는 결과를 보였으며 $(\mathrm{p}<0.001)$ 당도는 블랙커런트의 당도로 인 하여 첨가량과 비례하여 증가하는 결과를 보였다. 색도는 블랙커런트 첨가량이 증가할수록 $\mathrm{L}$ 값은 감소하였으며, $\mathrm{a}$ 값과 $\mathrm{b}$ 값은 증가하였다. 블랙커런트 첨가 요구르트 드레 싱의 유기산 결과 citric acid, malic acid, succinic acid, acetic acid는 블랙커런트 첨가량이 증가할수록 높게 나타났으며, tartaric acid와 lactic acid는 감소하는 것으로 나타났다. 요구 르트의 항산화능에서 총 페놀 함량은 대조군이 가장 낮았으 며, 블랙커런트 첨가량이 증가할수록 높게 나타났다. 안토 시아닌의 경우 대조군이 $0.62 \mathrm{mg} / 100 \mathrm{mg}$ 로 가장 낮았으며 블랙커런트 20\%첨가 요구르트 드레싱이 $190.09 \mathrm{mg} / 100$ $\mathrm{mg}$ 로 유의적으로 높게 나타났다(p<0.001). DPPH radical 소거능과 ABTS도 블랙커런트 첨가 요구르트 드레싱군이 대조군보다 높게 나타났으며 아질산염 소거능 또한 블랙커 런트 첨가량이 증가할수록 높게 나타나 블랙커런트를 첨가 함으로써 요구르트 드레싱의 항산화 효과를 증진시킬 수 있을 것으로 사료된다.

\section{References}

1. Lee HR, Jung BR, Park JY, Hwang IW, Kim SK, Choi JU, Lee SH, Chung SK (2008) Antioxidant activity and total phenolic contents of grape juice products in the Korean market. Korean J Food Preserv, 15, 445-449

2. Yu OK, Kim JE, Cha YS (2008) The quality characteristics of jelly added with Bokbunja (Rubus coreanus Miquel). J Korean Soc Food Sci Nutr, 37, 792-797

3. Chung HJ (2016) Comparison of bioactive constituents and biological activities of aronia, blackcurrant, and maquiberry. J Korean Soc Food Sci Nutr, 45, 1122-1129

4. Jin DH, Lee YG, Seong JH, Kim HS (2016) Comparison of bioactivities and antioxidant activities of acai berry (Euterpe oleracea Mart.) by different extraction solvents. J Korean Oil Chem Soc, 33, 741-750
5. Kim MH, Lee YJ, Kim DS, Kim DH (2003) Quality characteristics of fruits dressing. Korean Soc Food Cookery Sci, 19, 165-173

6. Kim HD, Lee YJ, Han JS (2002) A study of western food experience and the influence of sauce on food quality. J East Asian Diet Life, 12, 307-311

7. Bing DJ, Lee JH, Chun SS (2015) Quality characteristics and antioxidant activity of salad dressings prepared with wild grape powder during storage. J Korean Soc Food Sci Nutr, 44, 250-259

8. Lee KI (2004) The quality characteristics of sauce made with shrimp or crab. Korean J Soc Food Cookery Sci, 20, 164-169

9. Park KB (2014) Quality characteristics of yogurt dressing added with mulberry juice. Korean J Culinary Res, 20, 1-13

10. Kim HY, Jo HA (2010) Evaluation of microbial quality of the vegetable salad used dressing added with Prunus mnme extracts. Korean J Food Nutr, 23, 240-246

11. Kim KM, Lee HJ, Kim JS, Kim GC, Jang YE (2013) Quality characteristics of mayonnaise added with Yuza juice. Korean J Food Cookery Sci, 29, 733-739

12. Park JY, Lee SH, Park KB (2013) Quality characteristics of yogurt dressing added with Bokbunja (Rubus coreanus Miquel) juice. Korean J Culinary Res, 19, 23-35

13. Park KB, Kwon SY, Moon JH (2015) Quality characteristics of Aronia (Aronia melanocarpa) juice added yogurt dressing. Korean J Culinary Res, 21, 206-217

14. Lee WG, Lee JA (2012) Quality characteristics of yogurt dressing prepared with blueberry juice. Korean J Culinary Res, 18, 255-265

15. Sung JM, Choi HY (2014) Effect of mulberry powder on antioxidant activities and quality characteristics of yogurt. Korean Soc Food Sci Nutr, 43, 690-697

16. Hwangbo MH, Kim HJ, Yu MH, Lee JW, Lee IS (2006) Optimization of dressing preparation from yogurt added Saururus chinensis (Lour.) bail extract. Korean J Food Cookery Sci, 22, 22-29

17. AOAC (1995) Official Methods Analysis. $15^{\text {th }} \mathrm{ed}$, Association of Official Analytical Chemists. Washington DC, USA, p 69-90

18. Folin O, Denis W (1912) On phosphotungstic-phosphomolybdic compounds as color reagents. J Biol Chem, 12, 239-243

19. Yang JY, Jung SK, Song KM, Kim YH, Lee NH, Hong SP, Lee KH, Kim YE (2015) Quality characteristics of Sikhye made with berries. J East Asian Soc Diet Life, 
25, 1007-1017

20. Blois MS (1958) Antioxidant determinations by the use of a stable free radical. Nature, 181, 1199-1200

21. Re R, Pellegrini N, Proteggente A, Pannala A, Yang M, Rice-Evans C (1999) Antioxidant activity applying an improved ABTS radical cation decolorization assay. Free Radical Biol Med, 26, 1231-1237

22. Kim DB, Shin GH, Lee JS, Lee OH, Park IJ, Cho JH (2014) Antioxidant and nitrite scavenging activities of Acanthopanax senticosus extract fermented with different mushroom mycelia. Korean J Food Sci Technol, 46, 205-212

23. Jeong CH, Jang CW, Lee KY, Kim IH, Shim KH (2012) Chemical components and anti-oxidant activities of black currant. Korean J Food Preserv, 19, 263-270

24. Cho SK (2009) Quality characteristics of dressing added with mulberry. MS Thesis, Kyinggi University, Korea, p 37-38
25. Park MY, Chung HJ (2016) Effect of addition of blackcurrant powder of quality and antioxidant activity of Yanggaeng. J Korean Soc Food Cult, 31, 457-464

26. Kim MS, Sohn HY (2016) Anti-oxidant, anti-coagulation, and anti-platelet aggregation activities of blackcurrant (Ribes nigrum L.). J Life Sci, 26, 1400-1408

27. Bordonaba JG, Crespo P, Terry LA (2011) A new acetonitrile-free mobile phase for HPLC-DAD determination of individual anthocyanins in black currant and strawberry fruits: a comparison and validation study. Food Chem, 129, 1265-1273

28. Lee YM, Bae JH, Jung HY, Kim JH, Park DS (2011) Antioxidant activities in water and methanol extracts from Korean edible wild plants. J Korean Soc Food Sci Nutr, 40, 29-36

29. Cho NS, Chung HJ (2016) Qulity characateristics and antioxidant activity of Sulgidduk added with maquiberry powder. Korean J Food Preserv, 27, 945-952 